\title{
RESEARCH
}

Open Access

\section{Training needs assessment of agricultural extension change agents in the field of biological control of fruit fly in Sinai Peninsula}

\author{
Abdu Omran Mohamed ${ }^{1 *}$, Yousria Ahmed Allam ${ }^{1}$ and Ismail Ibrahim Hassen²
}

\begin{abstract}
Background: The context and purpose of the study. The world has turned to the technology of organic agriculture to obtain safe food and preserve the environment, and there have become many standards that control the production, processing, and circulation of organic products. Egypt has been interested in issuing a law to control organic agriculture, and has adopted a trend toward clean agriculture based on the use of organic fertilizers and bio-control of fruit flies. The research aimed to evaluate extension activities to improve training methods in this area, so as to estimate the level of training needs of agricultural extension agents in the field of biological control of fruit flies, and determine the training methods preferred by them, identify the reasons of weak application of the methods of biological control, identify the problems faced by extension agents to transfer biological control recommendations to farmers, and to identify the relationship between the level of training needs of agricultural extension workers and some independent variables. The methodology of the study depends on theoretical and analytical methods; data were collected by personal interview using questionnaire forms

Results: the main findings: The main findings are summarized as follows:

A It was found that more than three-quarter of change agents did not receive any training courses in this field, the attendees were low beneficiaries, so they are requiring further training in the field of biological control of fruit flies.

B There are severe training needs for agricultural extension agents for the methods of biological control of fruit fly in the following: pathogenic nematodes, growth regulators and hormones of reproduction, sterilization of male insects, and pathogenic bacteria.

C The agricultural extension agents prefer training methods as field visits and practical clarification

D There is a direct and significant relationship between the levels of training needs and age, and there are inverse and significant relationships with experience in training, academic qualification, academic specialization, the duration of service in agricultural work, the duration of service in extension work, and the degree of job satisfaction.

(Continued on next page)
\end{abstract}

\footnotetext{
* Correspondence: Abdoomran666@yahoo.com

${ }^{1}$ Agricultural Extension in the Department of Agricultural Economics,

National Research Centre, Cairo, Egypt

Full list of author information is available at the end of the article
}

\section{Springer Open}

(ㅇ The Author(s). 2020 Open Access This article is licensed under a Creative Commons Attribution 4.0 International License, which permits use, sharing, adaptation, distribution and reproduction in any medium or format, as long as you give appropriate credit to the original author(s) and the source, provide a link to the Creative Commons licence, and indicate if changes were made. The images or other third party material in this article are included in the article's Creative Commons licence, unless indicated otherwise in a credit line to the material. If material is not included in the article's Creative Commons licence and your intended use is not permitted by statutory regulation or exceeds the permitted use, you will need to obtain permission directly from the copyright holder. To view a copy of this licence, visit http://creativecommons.org/licenses/by/4.0/. 


\begin{abstract}
(Continued from previous page)
Conclusions: a brief summary and potential implication. Potential implication is to improve the extension services based on an assessment of the change agent's training needs, pay attention to the field demonstration in the training, and repeat it several times, and provide the trainers with auxiliary tools, while providing appropriate conditions for the fieldwork, increase agricultural programs on media broadcast to increase viewing, and support channels with research centers in order to facilitate its adoption and disseminate biological control methods in rural areas.
\end{abstract}

Keywords: Needs assessment, Biological control, Fruit fly, Agricultural change agents

\section{Background}

The agricultural sector is considered one of the most important sectors in the Egyptian economy due to its vital and effective role in the economic activity. This sector has witnessed a great development during the last period due to the introduction of modern and advanced technological methods which reflected on increasing the productivity of feddans from most agricultural crops (Specialized National Councils 1990, p. 4).

The world is witnessing an increasing trend toward the use of organic agriculture technology. The total cultivated areas of this technology reached about 25 million hectares and the volume of sales reached 40 billion dollars in 2005 . The world has turned to these technologies driven by many reasons, including the desire of consumers to obtain safe food. Contains no pesticide or chemical residue, reduce environmental degradation, preserve soil fertility and vitality by using organic fertilizers, maintain biodiversity, and maintain human health by avoiding consumption of food contaminated with chemicals, Cash Profit for Organic Agriculture (Hamdy 2006: 152)

From this perspective, Egypt has adopted a trend toward clean agriculture based on the use of organic fertilizers, biofertilizers, and bio-control of fruit flies for insect pests and diseases affecting various agricultural crops (Bahloul 1999: 2).

Where the area cultivated organically increased from 11.8 thousand feddans in 1999 to 43.2 thousand feddans in 2004 distributed over fifteen governorates (Kassem 2003: 20), has also been established a center for inspection of organic agriculture, the Center of Organic Agriculture in Egypt convinced of organic farming, the Egyptian Ministry of Agriculture has begun to add a new agriculture law that allows for the regulation of the use of these technologies The Central Department of Land, Water and Environment, as one of the specialized extension departments, has prepared an organic farming regulation that conforms to the regulations adopted by the European Common Market. Egypt has become one of the centers of organic agriculture production and has attracted the attention of importers from Europe and the world.

Many Egyptian companies started to enter this field, as the number of companies working in the field of organic agriculture reached 40 companies, Egypt now produces a large number of organic crops that fall under vegetables, fruits, field crops, medicinal and aromatic plants (Tolba 2008: 13), so organic agriculture must receive more attention to overcome the problems that lead to instability and related to the environment, humans, and animals.

Biological control is one of the most important elements of pest management. Biological control is also called "biological control."

It works to encourage or multiply the natural enemies of pests that are present in the same environment or import them and try to localize them and spread them widely to reduce pest reproduction, including pest enemies: parasites and predators.

Biocontrol also depends on the use of so-called biocides. The most important components are microbicides, which include different pathogens (fungi, bacteria, viruses, nematodes, and protozoa), pesticides resulting from fermentation processes of actinomycetes naturally found in the soil, and also include pheromones, pesticides extracted from plants, and genetically modified plants to resist pests (Al-Hunaidi and Fayyad 2004).

Egypt is one of the countries whose food production does not meet the growing needs of the population as the population growth rates always exceed the growth rates in agricultural production. Egypt's population has risen from 18.97 million in 1947 to about 83.6 million in 2012, while per capita agricultural land is declining from about 0.3 acres in 1947 to about 0.11 acres in 2012 .

Despite the state's efforts to increase the agricultural area, the erosion and loss of agricultural land is often equal to the total land reclaimed Egypt, where it lost more than 750 thousand acres of the best agricultural land in the Delta and Lower Egypt during the second half of the last century (CAPMAS, August 2015) (http://www.capmas.gov.eg/Pages/Publications.aspx?page_id=5104).

The successive economic and social development plans aimed at achieving comprehensive, balanced, and stable development in order to catch up with international and regional developments, and face the increase in population. Therefore, the state has turned to agricultural development, both vertical and horizontal, especially horizontal development in the new and newly 
reclaimed desert areas, such as the Sinai Peninsula. (information and support decision-making center in $\mathrm{Al}$ Arish: January 2005).

The state has paid special attention to the Sinai Peninsula in particular and established the National Project for the Development of Sinai, which was approved by the Council of Ministers in 1994, with the aim of achieving continuous development and employment of young people in the agricultural sector and securing the eastern borders of Egypt and ending the isolation of Sinai and linking it to the valley. The project consists of two stages: the first stage, the establishment of the canal of peace in front of the Dam and Lock Damietta to reclaim 220 thousand acres west of the Suez Canal has been completed; national infrastructure works are currently planting approximately 180 thousand acres and reclamation is 20 thousand acres. Stage II, construction of a siphon down the Suez Canal and the establishment of the Sheikh Jaber Al-Sabah Canal to reclaim 400,000 acres east of the Suez Canal (Ministry of Irrigation and Water Resources 2015 at http://www.mwri.gov.eg/project/sinai.aspx).

Sinai is famous for the production of some crops such as fruits such as peaches, apricots, pears, plums, apples, mangoes, guava, figs, almonds, olives, citrus fruits of various kinds, in addition to some vegetable crops cucurbits, eggplants, peppers, and tomatoes. These crops are affected by many pests of the most dangerous fruit fly, and there is a Mediterranean fruit fly insect throughout the year. This insect infects most of the fruits known in Egypt and in the entire Mediterranean region such as peaches, apricots, pears, plums, apples, mangoes, guava, figs, papaya, and citrus fruits of all kinds.

This pest was detected in Egypt in 1924 but was not of economic importance as it disappeared and then emerged since 1993 and began to infect the fruits of various fruits severely, has become a pest of the highest economic importance in a short period, with its appearance in the Egyptian environment, the numbers of the Mediterranean fruit fly began to decline in some areas as the high temperature and relative humidity increase the activity of the insect and shorten the period necessary to complete its life cycle. This climate is available in tropical and subtropical areas.

The fruit fly affects the following fruits:

- Citrus fruits in April and May.

- Apricots from early May to late June.

- Peaches from May to August and late varieties are severely affected.

- Pears from July to September.

- Mango from July to October.

- Guava and figs from July to November, especially in coastal areas.
- In winter citrus, the infection starts from September to November and the temperature decreases from December to February, thus decreasing the activity of the insect and then active from March to May. All citrus varieties are susceptible to infection, the most severe of which are mandarin, grapefruit, orange, navel and orange, and then the rest of citrus varieties (Hashim 2005).

Here, the importance of agricultural extension is highlighted as it provides informal education services to farmers to solve the problem of low agricultural productivity and resistance to pests and diseases.

Agricultural extension succeeds in performing its role in this field based on the competence and skills of workers, especially at the local level (agricultural extension workers) in terms of their ability to perform their tasks, which is determined in the light of the experience and training provided before and during their extension work (El-Safty 2007: 23). The training is one of the basic tasks and activities that help to raise the efficiency of agricultural extension workers and link them with modern innovations (Abul-Saud 1998: 24), and Pashat (1978, 13) emphasizes the importance of training that is essential to the development and success in all areas of life, through which individuals with the knowledge, skills, and attitudes that make them more efficient in the work they do, this was previously confirmed by Kelsey and Hearn (1963: 62 ) that the success of any training program is determined by studying the real situation and identifying actual needs and to identify desires and problems before starting implementation.

The improvement of the level of agricultural extension workers is linked to the design, planning, and implementation of training programs, which reflects the importance of studying the training needs and classifying them according to their priority (Ghaffar and Taha 1975: 226). (Abul-Saud 1997, p. 10) defines training needs as "lack of information, skills or attitudes that adversely affect the performance of a work or the attainment of the objectives of an organization."

From the above, it is clear that training needs represent a lack of one or more aspects of human behavior (information, skills, and attitudes) that affect the performance of individuals negatively.

This shortcoming can be addressed by three main aspects of the concept of training needs:

1- There is a lack of knowledge, skills, and attitudes of individuals to be trained. 
2- This deficiency is related to the actions or tasks of these individuals.

3- This deficiency is addressed by making changes in the behavior of individuals to reach the desired situation through training.

In order for agricultural extension agents to make desired behavioral changes in farmers' knowledge, skills, and attitudes to reduce the use of pesticides and chemical fertilizers, they need to be provided with positive information, skills, and trends in the field of bio-control. Some studies dealing with training needs in researchrelated subjects showed that $81 \%$ of agricultural extension agents from the research sample had a training need in the field of biological control (Hassan 2000), and $62.4 \%$ of agricultural extension agents had a high training need in the field of pesticide use (Sharaf 1990).

In view of the lack of studies on the training needs in the field of bio-control and the current interest in extension to push farmers to apply the technical practices of organic agriculture, which depends largely on the knowledge and skills of agricultural extension workers.

In light of the above elements, the problem of the study seeks to answer the following questions:

- What are the training needs of agricultural extension workers in the field of biological control of fruit fly?

- What are the training methods preferred by agricultural extension agents for training in the field of biological control of fruit flies?

- What are the reasons for the weak acceptance of farmers for the application of methods of biological control of fruit flies from the point of view of extension workers?

- What are the problems faced by extension agents to transfer biological control of the fruit fly recommendations to farmers?

- What is the relationship between the level of training needs of agricultural extension workers in the field of biological control of fruit flies as a dependent variable and the independent studied variables?

\section{Research objectives}

To resolve the previously presented research problem, the following objectives were identified:

1. Determine the level of training needs of agricultural extension agents in the field of bio-control of fruit flies

2. Determine the training methods preferred by agricultural extension agents for training in the field of biological control of fruit flies
3. Identify the reasons for the weak acceptance of farmers for the application of methods of biological control of fruit flies from the point of view of extension workers

4. Identify the problems faced by extension agents to transfer biological control of the fruit fly recommendations to farmers

5. Determine the relationship between the level of training needs of agricultural extension agents in the field of biological control of fruit flies as a dependent factor and the independent studied variables

\section{Methods}

The methodology of the study depends on theoretical and analytical methods, it was to evaluate extension activities to improve training activities in this area, so a regular random sample of 108 agricultural extension agents was chosen in the study. Data were collected by personal interviews using questionnaire forms, and for data analysis, the statistical program (SPSS) was used, the arithmetic mean and Pearson's simple correlation coefficient (R) was used in the analysis of the data. The results were presented in the form of percentages and percentages of the mean.

\section{Search area}

This research was conducted in the Sinai Peninsula, which is divided into North Sinai Governorate and South Sinai Governorate, which the state strives to rebuild as it is considered the strategic depth of Egypt from the east, in other words, it is the gate of East Egypt, which is the link between Egypt and the Arab Asian countries. The area of the Sinai Peninsula is about 60 thousand square kilometers. The area of North Sinai Governorate is approximately 28 thousand square kilometers, and South Sinai Governorate 32 is approximately $1000 \mathrm{~km}^{2}$.

\section{South Sinai Governorate}

South Sinai is located between the Gulf of Aqaba in the east and the Gulf of Suez in the west and lies between the latitude of 28 degrees south and 31.5 degrees north of the equator. The total area of the governorate of South Sinai $(32,000) \mathrm{km}^{2}$ consists of the governorate in terms of the administrative division of the following: Tor Sinai City, Ras Sidr, Abu Dhneima City, Abu Redis City, St. Catherine City, Sharm El Sheikh City, Dahab City, Nuweiba City.

The total cultivated area in the governorate is 8200 feddans, the percentage of cultivated area to the total area $(0.11 \%)$, and the total crop area (8500 feddans). 
The most important crops include fruits, vegetables, wheat, and barley (Information and Decision Support Center in Ras Sidr 2002).

\section{North Sinai Governorate}

It is considered one of the largest desert areas in Egypt in terms of the intensity of agricultural extension work. In addition, the Faculty of Agricultural and Environmental Sciences in Al-Arish provides agricultural extension services to the farmers of the governorate, in addition to the presence of 2 regional research stations belonging to the Desert Research Center in both Sheikh Zuwaid, and Al-Hassana plays a significant role in agricultural extension with workers in the agricultural field in various agricultural departments in North Sinai (Agricultural Directorate of North Sinai Governorate 2015).

\section{The research sample}

The research comprehensive includes all agricultural extension workers working in agricultural extension in the two governorates, as the research comprehensive reached 154 agricultural extension workers distributed in extension sectors covering the centers (Table 1).

The research sample was chosen from the total number of agricultural extension agents in the governorate based on the "Kregice and Morgan 1970: 610-607" equation:

$$
S=X^{2} P N(1-P) \div d^{2}(N-1)+X^{2} P(1-P)
$$

By applying the previous equation to the total number of workers in agricultural extension in the two governorates of North and South Sinai, which numbered 154 with a total of $131+33$, the size of the research sample reached 108 respondents.

Table 1 A statement of the number of departments and the guidance inspectors and guides at the level of North and South Sinai

\begin{tabular}{lll}
\hline The statement & $\begin{array}{l}\text { North Sinai } \\
\text { Governorate }\end{array}$ & $\begin{array}{l}\text { South Sinai } \\
\text { Governorate }\end{array}$ \\
\hline $\begin{array}{l}\text { The number of agricultural } \\
\text { extension inspectors }\end{array}$ & 7 & 4 \\
$\begin{array}{l}\text { The statistical number of the } \\
\text { directorate }\end{array}$ & 8 & 6 \\
$\begin{array}{l}\text { The statistical number of the } \\
\text { administration }\end{array}$ & 21 & 8 \\
$\begin{array}{l}\text { The number of guides in the } \\
\text { villages }\end{array}$ & 85 & 15 \\
Total & 121 & 33 \\
\hline
\end{tabular}

(Directorate of Agriculture, North and South Sinai governorates 2019)

\section{Method and tool of data collection}

The sample members were chosen intentionally, as they were limited to 85 village guides in North Sinai Governorate, and they were limited to 15 village guides, and the agricultural administration statistic of 8 specialists in a total of 23 researchers in South Sinai Governorate, with a total of 108 guides.

A questionnaire was used in the personal interview as a tool to collect the necessary data for the research. It was prepared and made sure of its validity and clarity of its phrases through an initial test applied to 15 respondents. The field data was collected during the month of March 2019.

\section{Quantification of data \\ The data related to the studied independent variables}

Age It means the age of the respondent to the nearest Gregorian year. This variable was expressed by the raw number of the respondent's age at the time of collecting the research data. The minimum age of the respondents is 23 years. The upper limit is 58 years, with a range of 35 , and the respondents were divided according to their age into the following categories: young (less than 35 years), middle-aged (35-less than 47 years), elderly ( 47 years and over).

Academic qualification It means the highest educational qualification obtained by the respondent and this variable were measured by asking the respondent about his educational condition, and the respondents section in terms of their educational status into three categories: intermediate qualification (one degree), university degree (two degrees), postgraduate degree (three degrees).

Academic specialization It refers to the type of academic specialization of the mentor. The subjects were divided in terms of their academic specialization into two categories: agricultural extension (three grades), general (two grades), and other specializations (one degree).

Duration of service in agricultural work It means the number of years the researcher spent in agricultural work for the earliest Gregorian year, this variable has been expressed by the raw number of the number of years the researcher spent in agricultural work, at the time of collecting the research data, and the minimum period of the respondents was 1 year and the maximum is 35 years, with a range of 34 and the respondents were distributed according to the following categories: the service period is small (less than 12 years), the average service period (12-less than 23 years), the service period is large (23 years or more). 
Duration of service in extension work It means the number of years the respondent spent in agricultural extension for the nearest calendar year. This variable was expressed in the raw number of the number of years the researcher spent in agricultural extension, at the time of collecting the research data, and the minimum period of the respondents reached 1 year and a maximum of 26 years, with a range of 25 . The subjects were distributed according to a period of time into the following categories: duration of service is small (less than 10 years), average service period (10-less than 19 years), long service life (19 years and over).

Genesis It means the nature of the establishment of the agricultural extension in terms of being rural or urban in the genesis, and this variable has been measured by giving two degrees in the case of the rural extension of the extension, and one degree in the case of urban development for him as follows: rural genesis (two degrees), urban Genesis (one degree).

Place of residence It means the distance of the place of work from the place of residence, and this variable was measured by giving the same village (three degrees), another village (two degrees), and the city (one degree).

Training experience It means the total of what the guide attended during his service period of courses, and this variable was measured by asking the respondents about the number of these courses and it was expressed in the raw number, and the minimum period of the respondents (did not take courses) and the upper limit 7 courses, with a range of 7 . The subjects were distributed according to a period of time into the following categories: small training experience (less than 3 courses), medium training experience (3-less than 5 courses), great training experience ( 5 courses or more).

The number of training courses attended by the guide on the control of pest control of the fruit fly It means the total of what the guide attended during his service period of courses on the control of the fruit fly, and this variable was measured by asking the respondents about the number of these courses and it was expressed in the raw number.

The degree of job satisfaction It means a set of psychological and functional factors and environmental conditions that make the employee satisfied with his work in agricultural extension, and a variable consisting of 11 terms was used in measuring this variable, each of which was considered a gradient of response patterns, which consists of three responses that are OK. To some extent, it is not $\mathrm{OK}$, and these responses have been given scores that are between 3 and 1 in the case of positive statements, and vice versa in the case of negative phrases. He has a degree of job satisfaction for the respondents, and the maximum degree of degree according to this scale has reached 31 degrees, and the minimum degree is 11 degrees, with a span of $20 \mathrm{sec}-$ tions into three categories, namely, low job satisfaction (less than 18 degrees), medium job satisfaction (from 18less than 25 degrees), great job satisfaction (25 and over).

Extent of benefit from attending training courses It means the degree to which the mentors of the respondents benefit from attending the training courses, and this variable was measured by asking the respondents about the extent of their benefit from these activities through the use of a scale consisting of three categories (low, medium, high). Those responses were given scores for each response as follows: low benefit (1 degree), medium training experience (3-less than 5 degrees), high utilization (three degrees).

The extent of benefit from attending training courses on the the bio-pest control of fruit flies The degree to which the guide guides benefit from attending training courses in the field of the bio-pest control of the fruit fly, and this variable was measured by asking the researchers about the extent of their benefit from these activities through the use of a component scale. Of the three categories (low, medium, high), those responses were given grades related to each response as follows: low utilization (one degree), medium benefit (two grades), high utilization (three degrees).

\section{Dependent variable}

Training needs of extension workers in the field of the bio-pest control of the fruit fly (biological) The degree of training needs of the respondents was measured in biological control. The views of the respondents were investigated on the extent of their need for training in the knowledge related to the use of both biological control methods.

1. Jamming Pheromone: The respondents were asked about their need for related knowledge through (5 items).

2. Sexual attractiveness: The respondents' opinions were investigated on the extent of their need for related knowledge through (4 items).

3. Pathogenic bacteria: The opinions of the respondents were investigated on the extent of their need for related knowledge through (4 items). 
4. Nurse nematodes: The respondents were asked about their need for related knowledge through (2 items).

5. Growth regulators and dissociation hormones: The respondents were asked about their need for related knowledge through (1 item).

6. Sterilization of male insects: The respondents' opinions were investigated on the extent of their need for related knowledge through (2 items).

And this is done through a graduated scale of two levels which are (need, and does not need), and grades 2 and 1 have been given, and the maximum degree of degree according to this scale has reached 36 degrees, and the minimum is 18 degrees, with a range of 18 sections into three categories which are as follows: low need (less than 24 degrees), medium need (24-30 degrees), and severe need (30 degrees or more).

The number and percentage were calculated for each of the two categories he needs, and does not need, and the average score for the respondents expressing the training need for them was calculated in each of the studied methods, then according to the percentages of the average degrees of need in a particular method by dividing the average levels of need for this method by the maximum of it, multiplied by 100, and according to the percentage of the average levels of training need for the respondents, the training need for them was divided into three levels, severe training need $76 \%$ or more, average training need $50-75 \%$, low training need less than $50 \%$.

\section{Metadata}

Training methods preferred by agricultural extension agents for training in the field of the bio-pest control of fruit flies With regard to extension training methods preferred by agricultural extension agents for training in the field of organic agriculture, it was measured through the researcher's question on six training methods which are (workshops, practical clarification, seminars, guidance, discussions, lectures, field visits) through a scaled scale of two levels (it prefers, not favors), and grades 2 and 1 are given to these responses respectively, and are arranged according to the percentage of the average.

Reasons for the reluctance of farmers to apply the methods of the bio-pest control of the fruit fly from the point of view of the mentors With regard to the reasons for the reluctance of farmers to apply the methods of the bio-pest control of Drosophila from the point of view of the guides. A variable consisting of 9 phrases was used in measuring this variable, through a scale of two levels (yes and no), and grades 2 and 1 were given for these responses, respectively, and were arranged according to the average percentage.

The problems facing the guides in the field of the pest control of the fruit fly Regarding the problems facing the guides in the field of the bio-pest control of the Drosophila, a measure consisting of 16 problems was used in measuring this variable through a graded scale of two levels (yes and no), and grades 2 and 1, and responses were given, respectively, and funding by average percentage.

\section{Statistical analysis tools}

Use the data analysis of the statistical program (SPSS Statistical package for social science), and the arithmetic average, the coefficient of simple correlation of Pearson and results were displayed using frequencies and percentages, and the percentage of the average, in tabular image.

\section{Results}

Description of the personal, professional, social, and economic independent variables in the study

The results (Table 2) showed the following: The results indicate that about $42.6 \%$ of the respondents are of middle age and under the age of 47 years, $53.7 \%$ of them have university qualifications, very few are specialists in agricultural extension, and more than $53 \%$ have other specialties.

Half of them are in the middle class from 12 to 23 years in agricultural work, but $60 \%$ of them are in extension work for a small period (less than 10 years).

It turned out that most of them originated urban and most of the residents in the city, sixty percent of them are highly satisfied with their job.

As for the training experience, it was found that $40.7 \%$ had small training experience (less than 3 courses) and $39 \%$ had received 5 courses or more, while a large percentage did not get a specialized course in bioresistance.

-Distribution of respondents according to their benefit from attending the bio-pest control course

The results of Table 3 indicate that more than threequarter of the respondents (78.7\%) did not get the course, while $(7.4 \%)$ their utilization is low, while it was found that only $13.9 \%$ of them benefited from medium, which reflects the need for training efforts for agricultural extension workers in the field of biological control of fruit flies. 
Table 2 Distribution of the surveyed extension agents according to their distinctive characteristics

\begin{tabular}{|c|c|c|}
\hline Characteristics & No. & $\%$ \\
\hline \multicolumn{3}{|l|}{ 1. Age } \\
\hline Young (under 35 years) & 21 & 19.44 \\
\hline Middle age (35-47 years) & 46 & 42.60 \\
\hline Elderly (over 47 years) & 41 & 37.96 \\
\hline \multicolumn{3}{|l|}{ 2. Educational qualification } \\
\hline Intermediate certificate & 42 & 39.9 \\
\hline College degree & 58 & 53.7 \\
\hline Postgraduate & 8 & 7.4 \\
\hline \multicolumn{3}{|l|}{ 3. Study specialization } \\
\hline Agricultural extension & 1 & 0.9 \\
\hline Other specialties & 59 & 53.7 \\
\hline General specialty & 48 & 44.4 \\
\hline \multicolumn{3}{|l|}{ 4. Duration of service in agricultural work } \\
\hline Small service life (less than 12 years) & 19 & 17.6 \\
\hline Average service life (12-less than 23) & 47 & 43.5 \\
\hline Large service life ( 23 years and above) & 42 & 38.9 \\
\hline \multicolumn{3}{|l|}{ 5. Duration of service in extension work } \\
\hline Small service life (less than 10 years) & 64 & 59.25 \\
\hline Medium service life (10-less than 19) & 27 & 25 \\
\hline Large service period (19years and above) & 17 & 15.75 \\
\hline \multicolumn{3}{|l|}{ 6. Growing up } \\
\hline Urban & 74 & 68.5 \\
\hline Rural & 34 & 31.5 \\
\hline \multicolumn{3}{|l|}{ 7. Place of residence } \\
\hline The same village (three degrees) & 1 & 0.9 \\
\hline Another village (2 degrees) & 16 & 14.8 \\
\hline City (one degree) & 91 & 84.3 \\
\hline \multicolumn{3}{|l|}{ 8. Training experience } \\
\hline Small training experience (less than 3 courses) & 44 & 40.7 \\
\hline Medium experience (3-less than 5 courses) & 22 & 20.4 \\
\hline $\begin{array}{l}\text { Significant training experience (from } 5 \text { courses and } \\
\text { above) }\end{array}$ & 42 & 38.9 \\
\hline \multicolumn{3}{|l|}{ 9. Number of attending specialized training courses } \\
\hline Never got any course & 85 & 78.7 \\
\hline Attended one course & 23 & 21.3 \\
\hline \multicolumn{3}{|l|}{ 10. Degree of job satisfaction } \\
\hline Low job satisfaction (less than 18 degrees) & 4 & 3.7 \\
\hline Average Satisfaction (18- > 25) & 39 & 36.1 \\
\hline Large Job Satisfaction (25+) & 65 & 0.2 \\
\hline
\end{tabular}

Training needs of extension workers in the field of biological resistance (the dependent variable)

The results of Table 4 indicate that most of the respondents have a severe need for training (88\%), while (8.3\%)
Table 3 Distribution of the extension agents according to their benefit from attending the biological pest control course

\begin{tabular}{lll}
\hline Attend specialized training & No. & $\%$ \\
\hline Did not get the course & 85 & 78.7 \\
Low & 8 & 7.4 \\
Average & 15 & 13.9 \\
Total & 108 & 100 \\
\hline
\end{tabular}

have an average need, while it was found that only (3.7\%) of them had low needs.

The results shown in Table 5 showed that agricultural extension workers have a high level of training needs in relation to the methods of biological control of fruit fly (pathogenic nematodes, growth regulators and reproductive hormones, sterilization of male insects, pathogenic bacteria), where the average percentage of the respondents' training needs for these methods (95\%, $94 \%, 92 \%, 84 \%)$, respectively, the average score of the respondents' knowledge of these practices was (1.90, 1.88, $1.84,1.68)$, respectively, while the extension agents were found to have an average need in pheromone jammer, sex pheromone. The average percentage of respondents' training needs for these methods (70\% and 67\%), respectively, and the average degree of respondents' knowledge of these practices $(1,40,1,34)$, respectively.

\section{Metadata}

Training methods preferred by agricultural extension workers in the field of biological control of fruit fly

The results are presented in Table 6. The first rank in the training methods that the counselors prefer for training in the field of vital resistance are field visits, where $99 \%$ prefer it with an average of 1.98 , and the practical clarification ranked second as $97 \%$ with an average of 1.94 . With an average of 1.85 , while the workshops ranked fourth, $90.5 \%$ preferred them with an average of 1.81 , while the discussions occupied the fifth position with an average of $87.5 \%$ with an average of 1.75 , while the lectures were in the last position where $85 \%$ preferred it with an average 1.70 .

Table 4 Distribution of extension agents according to the degree of their training needs in the field of biological control of fruit flies

\begin{tabular}{lll}
\hline Level of training needs & No. & $\%$ \\
\hline Low need (less than 24 degrees) & 4 & 3.7 \\
Average need (24-30 degrees below) & 9 & 8.3 \\
severe need (30 degrees and above) & 95 & 88 \\
Total & 108 & 100 \\
\hline
\end{tabular}


Table 5 Distribution of extension change agents according to their training needs in bio resistance methods

\begin{tabular}{llllll}
\hline Biological control methods & Maximum training needs & Average & $\%$ & Needs & Ranking \\
\hline Pheromone jammer & 10 & 1.40 & 70 & Average & 5 \\
Sex pheromone attractants & 8 & 1.34 & 67 & Average & 6 \\
Pathogenic bacteria & 8 & 1.68 & 84 & Severe & 4 \\
Pathogenic nematodes & 4 & 1.90 & 95 & Severe & 1 \\
Growth regulators and reproductive hormones & 2 & 1.88 & 94 & Severe & 2 \\
Sterilization of male insects & 4 & 1.84 & 92 & Severe & 3 \\
\hline
\end{tabular}

The total number of respondents 108

Reasons for the reluctance of farmers to apply the methods of the bio-pest control of the fruit fly from the point of the agricultural extension agents

The results presented in Table 7 indicate that there is a noticeable increase in the reasons for the farmers' reluctance to apply the methods of the bio-pest control of the fruit fly from the point of the agricultural extension as follows: a lack of knowledge and information farmers for the bio-pest control methods ranked first, $96.5 \%$ with an average of $1.93 \%$, while lack of supplies for popular control of fruit flies, and weak communication channels between research and agricultural extension and research centers ranked second, with acknowledgment of their existence, 95\% with an average of 1.90, followed by the third place, was the lack of awareness of the farmers about the effects of pesticides and chemical fertilizers on the environment, as it was recognized as having 90.5\% with an average of 1.81, while the lack of conviction of the farmers with the bio-pest control of the fruit fly and led them to the imperative to use chemicals to produce productivity agricultural ranked fourth, with an average of $89.5 \%$ acknowledged its existence (1.79), and in fifth place came a lack of informative brochures and posters about the pest control of the Drosophila, as it recognized $87.5 \%$ with an average of 1.75. And came in sixth place, agricultural holdings disintegrated, as it recognized $87 \%$ with an average of 1.74, while the lack of guidance tools for the pest control of fruit flies to educate farmers came in the seventh place, as it included $84 \%$ with an average of 1.68. Farmers do not believe in the high costs of the pest control of the Drosophila, which ranks last, with an average of $83.5 \%$ being recognized (1.67).

\section{Problems facing extension workers in the field of bio- control of fruit flies}

The results in Table 8 indicate that there are several problems facing extension workers in the field of biocontrol of fruit flies, such as follows:

- Lack of incentives and financial rewards for them in the first place, where $90.5 \%$ of extension workers mentioned with an average of 1.91, then the problem of the lack of supply of rural programs for bio-l control in television in the second rank has mentioned $89.5 \%$ with an average of 1.89 , then the problem of the lack of extension means in the third rank, where they mentioned $84 \%$ with an average of 1.85 , then came in the fourth rank short time period of training courses for the extension workers, and the lack of change agents' number, where it has mentioned $83.2 \%$ with an average of 1.83 .

- Then, the problem of adhering to the old when biological control of fruit flies ranked fifth with $81.1 \%$ with an average of 1.81 , then the problem of

Table 6 Distribution of agricultural extension agents according to training methods they prefer for training in bio-control of fruit

\begin{tabular}{|c|c|c|c|c|c|c|c|c|}
\hline \multirow[t]{2}{*}{ No. } & \multirow[t]{2}{*}{ Training methods } & \multicolumn{2}{|c|}{ Favorite } & \multicolumn{2}{|c|}{ Not favorite } & \multirow[t]{2}{*}{ Mean } & \multirow[t]{2}{*}{$\%$} & \multirow[t]{2}{*}{ Rank } \\
\hline & & No. & $\%$ & No. & $\%$ & & & \\
\hline 1 & Field visits & 106 & 98.1 & 2 & 1.9 & 1.98 & 99 & 1 \\
\hline 2 & Practical demonstration & 101 & 93.5 & 7 & 6.5 & 1.94 & 97 & 2 \\
\hline 3 & Seminars & 92 & 85.2 & 16 & 14.8 & 1.85 & 92.5 & 3 \\
\hline 4 & Discussions & 81 & 75 & 27 & 25 & 1.75 & 87.5 & 5 \\
\hline 5 & Lectures & 76 & 70.4 & 32 & 29.6 & 1.70 & 85 & 6 \\
\hline 6 & Workshops & 87 & 80.6 & 21 & 19.4 & 1.81 & 90.5 & 4 \\
\hline
\end{tabular}


Table 7 Distribution of the researched guides according to the reasons the farmers are reluctant to apply the pest control methods of the fruit fly from their point of view

\begin{tabular}{|c|c|c|c|c|c|c|c|}
\hline \multirow[t]{2}{*}{ Reasons } & \multicolumn{2}{|c|}{ Exist } & \multicolumn{2}{|c|}{$\begin{array}{l}\text { Non- } \\
\text { existent }\end{array}$} & \multirow[t]{2}{*}{ Mean } & \multirow[t]{2}{*}{$\%$} & \multirow[t]{2}{*}{ Rank } \\
\hline & No. & $\%$ & No. & $\%$ & & & \\
\hline Lack of farmers' knowledge and information on bio-control methods of fruit flies & 96 & 88.9 & 12 & 11.2 & 1.93 & 96.5 & 1 \\
\hline Small size of agricultural holdings & 32 & 29.6 & 76 & 70.4 & 1.74 & 87 & 6 \\
\hline Lack of specialized extension seminars to educate farmers & 71 & 65.7 & 37 & 34.3 & 1.68 & 84 & 7 \\
\hline Lack of specialized bulletins and posters & 77 & 71.3 & 31 & 28.7 & 1.75 & 87.5 & 5 \\
\hline $\begin{array}{l}\text { Lack of farmers' awareness of the effects of pesticides and chemical fertilizers on the } \\
\text { environment }\end{array}$ & 84 & 71.3 & 24 & 28.7 & 1.81 & 90.5 & 3 \\
\hline Weak communication channels between research centers, agricultural extension, and farmers & 93 & 86.1 & 15 & 13.9 & 1.90 & 95 & 2 \\
\hline Failure to provide the fruit fly application for biological control & 93 & 86.1 & 15 & 13.9 & 1.90 & 95 & 2 \\
\hline $\begin{array}{l}\text { Farmers are not convinced of the biological control of fruit flies and believe that chemicals } \\
\text { should be used to increase agricultural productivity }\end{array}$ & 85 & 78.7 & 23 & 21.3 & 1.79 & 89.5 & 4 \\
\hline Farmers' belief in the high cost of bio-control of fruit flies and reduced production & 84 & 77.8 & 24 & 22.2 & 1.67 & 83.5 & 8 \\
\hline
\end{tabular}

lack of training programs for extension workers in the field of biological control of the fruit fly, where it was mentioned by $80 \%$ with an average of 1.81 . In the seventh order was the lack of material resources for extension work, and lack specialized bulletins on bio-control of fruit flies where they were mentioned $76.8 \%$ with an average of 1.77 .

- Then the problem of weak participation of farmers in extension seminars in the eighth order, where they mentioned $74.7 \%$ with an average of 1.75 , followed by the problem of the late arrival of agricultural extension publications in the ninth order, where $70.5 \%$ mentioned with an average of 1.71 , followed by the problem of illiteracy of the majority of farmers in the tenth order, where it mentioned $69.5 \%$ with an average of 1.69 , then the problem of assigning agricultural extension workers other administrative work in the eleventh order, they mentioned $68.4 \%$ with an average of (1.68), and finally, the administrative problems in the work

Table 8 Distribution of agricultural extension agents according to the problems facing extension agents in the field of biological control of fruit flies

\begin{tabular}{|c|c|c|c|c|c|c|c|}
\hline \multirow[t]{2}{*}{ The problems facing extension agents } & \multicolumn{2}{|c|}{ Exist } & \multicolumn{2}{|c|}{ Non-existent } & \multirow[t]{2}{*}{ Mean } & \multirow[t]{2}{*}{$\%$} & \multirow[t]{2}{*}{ Rank } \\
\hline & No & $\%$ & No & $\%$ & & & \\
\hline Lack of material resources for extension work & 83 & 76.8 & 25 & 23.2 & 1.77 & 76.8 & 7 \\
\hline Belief in ancient pest control practices & 88 & 81.1 & 20 & 18.9 & 1.81 & 81.1 & 5 \\
\hline Assigning agricultural extension workers to other administrative work & 74 & 68.4 & 34 & 31.6 & 1.68 & 68.4 & 11 \\
\hline Lack of financial incentives and rewards & 98 & 90.5 & 10 & 9.5 & 1.91 & 90.5 & 1 \\
\hline Decrease in the number of extension agents & 90 & 83.2 & 18 & 16.8 & 1.83 & 83.2 & 4 \\
\hline Lack of rural programs in TV in the field of biological resistance & 97 & 89.5 & 11 & 10.5 & 1.89 & 89.5 & 2 \\
\hline Lack of bulletins on fruit flies biological control & 83 & 76.8 & 25 & 23.2 & 1.77 & 76.8 & 7 \\
\hline Lack of extension means & 91 & 84 & 17 & 16 & 1.85 & 83.2 & 3 \\
\hline Lack of training programs for extension workers in the field of bio-control of fruit fly & 86 & 80 & 22 & 20 & 1.80 & 80 & 6 \\
\hline Shortening the training course duration & 90 & 83.2 & 18 & 16.8 & 1.83 & 83.2 & 4 \\
\hline Administrative problems at work & 69 & 64.2 & 37 & 35.8 & 1.64 & 1.64 & 12 \\
\hline Weak participation of farmers in extension seminars & 81 & 74.7 & 27 & 25.3 & 1.75 & 74.7 & 8 \\
\hline Lack of means of transportation for agricultural workers & 90 & 83.2 & 18 & 16.8 & 1.83 & 83.2 & 4 \\
\hline Delayed arrival of agricultural extension publications & 76 & 70.5 & 32 & 29.5 & 1.71 & 70.5 & 9 \\
\hline Illiterate majority of farmers & 75 & 69.5 & 33 & 30.5 & 1.69 & 69.5 & 10 \\
\hline
\end{tabular}


ranked last with $64.2 \%$ with an average (1.64). This calls for the agricultural extension and other bodies concerned with the Ministry of Agriculture, to work on the need to study and solve those problems facing agricultural extension workers and hinder their work in the dissemination of agricultural techniques.

\section{The relationship between the levels of training needs of agricultural extension workers in the field of biological control of fruit fly as a dependent variable and some independent variables}

The following statistical hypothesis was formulated: "There is no significant relationship between the level of training needs of agricultural extension workers in the field of bio-control of fruit flies as a dependent variable and each of the following independent variables studied: age, qualification, academic specialization, duration of service in agricultural work, and length of service at work. Upbringing, place of residence, training experience and degree of job satisfaction."

By testing the validity of the hypothesis using the simple correlation coefficient of Pearson $(t)$, it was clear as shown in Table 9 that there is a positive correlation at the level of significance, 0.01 between the level of training needs of agricultural extension agents, and the age variable where the value of $(r)$ calculated as 0.248 , which indicates that as the age of the change agent, increases the training need in bio-control of fruit flies.

- There was also a significant inverse relationship at the level of significance 0.01 between the level of training needs of agricultural extension workers in the field of bio-control of fruit fly and the training experience where it was found that the training experience with a value of $(r)$ calculated as -0.246 ,

Table 9 The correlation coefficients for the relationship between the training needs of agricultural extension workers in the field of biological control and some independent variables

\begin{tabular}{ll}
\hline Independent variables studied & $\begin{array}{l}\text { Pearson simple correlation } \\
\text { coefficient values }(\boldsymbol{r})\end{array}$ \\
\hline Age & $0.248^{* *}$ \\
Educational Qualification & $-0.192^{*}$ \\
Specialization & $-0189^{*}$ \\
Duration of service in & $-0.191^{*}$ \\
agricultural work & \\
Duration of service in & $-0.185^{*}$ \\
extension work & \\
Growing up & 0.106 \\
Residence & -0.40 \\
Training experience & $-0.246^{* *}$ \\
Degree of job satisfaction & $-0.184^{*}$ \\
\hline
\end{tabular}

which is greater than its spreadsheet counterpart at the same level, which is reflected. The increase in training experience reduces the training needs.

- It was also found that there was a significant inverse relationship at the level of 0.05 between the level of training needs of agricultural extension workers in the field of biological control of fruit flies as a dependent variable and the following independent variables: the academic qualification is $(r)$ calculated as 0.192 , the specialization is $(r)$ calculated as -0.189 , the duration of service in agricultural work is $(r)$ calculated as -0.191 , and the duration of service in extension work is $(r)$ calculated as 0.185 . They are larger than their spreadsheet counterparts at the same level.

- There is no significant relationship between the level of training needs of agricultural extension workers in the field of bio-control of fruit fly and origin, and place of residence.

\section{Discussion}

Change agents are requiring further training in the field of biological control of fruit fly especially in the following methods: pathogenic nematodes, growth regulators, and reproductive hormones, sterilization of male insects, pathogenic bacteria.

Training methods have been used, field visits and practical clarification, which are preferable by extension workers.

It is important to provide farmers with knowledge and information about these methods, support them with supplies of biological control, and enhance communication channels between research centers and agricultural extension in order to facilitate its adoption and disseminate biological control methods in rural areas.

In order to motivate agricultural change agents to act more active are increasing incentives and financial rewards and increasing rural programs in television in this area. In selecting trainees to benefit from training courses in the field of biological control, they have an experience in training, have an academic qualification, have an academic specialization, have a long duration of service in agricultural work, especially in extension work, and have job satisfaction.

\section{Conclusion}

To overcome the problem of a lack of numbers of agricultural extension workers to help spread and adopt the bio-control practices, agricultural engineers in the directorates can be qualified to provide guidance work by conducting intensive training sessions to use practical demonstration methods and simplifying practices for 
farmers and repeat their presentation in agricultural programs on television to increase viewing, as for the increase in incentives for extension workers, the budget allocated to agricultural extension is weak and difficult to achieve, but at least it provides comfortable transportation means for them.

\section{Acknowledgements}

Our thanks and appreciation to the Directorate of Agriculture, North Sinai Governorate, and the Agricultural extension workers for their assistance in making data available and helping to collect questionnaires.

\section{Authors' contributions}

He prepared the study in terms of formulating the idea and setting goals. Preparing the questionnaire and writing the research and commenting on the results-Dr. A.O.Mohamed. She collected primary and field data and collected the questionnaire from the agricultural extension change agents-Dr. Y.A.Allam. Performed the statistical analysis-Dr. I.I.Hassen. All authors read and approved the final manuscript.

\section{Funding}

Self-finance.

\section{Availability of data and materials}

Data is available in reference numbers $4,7,8$, and 9.

\section{Ethics approval and consent to participate}

Not applicable.

\section{Consent for publication}

Not applicable.

\section{Competing interests}

Not applicable.

\section{Author details}

${ }^{1}$ Agricultural Extension in the Department of Agricultural Economics, National Research Centre, Cairo, Egypt. ${ }^{2}$ Agricultural Extension Department, Azhar University, Cairo, Egypt.

Received: 1 February 2020 Accepted: 17 August 2020

Published online: 31 August 2020

\section{References}

Abul-Saud KH (1998) "Preparation and training of agricultural extension workers in the Arab world", conference of agricultural extension and the challenges of agricultural development in the Arab world - Arab Council for Graduate Studies and Scientific Research. Federation of Arab Universities, Cairo

Abul-Saud KH (1997) "Training", the project of integrating population culture in agricultural extension, General Directorate of Agricultural Extension, Ministry of Agriculture and Land Reclamation. Arab Republic of Egypt in partnership with FAO and the United Nations Population Fund, Cairo

Al-Hunaidi, Ahmed Hussein, and Fayyad, Yahia Hussein (2004): "Bio-control of insect pests", Ministry of Agriculture and Land Reclamation in Cairo, Agricultural Research Center, Central Administration for Agricultural Extension, Bulletin No. 900.

Bahloul, Ahmed Kadry (1999): "The impact of chemical technology on the continuous agricultural development in Egypt", The Seventh Conference of Agricultural Economists, Egyptian Technology and Agriculture in the 21st Century, Egyptian Agricultural Economics Association, 28-29 July.

El-Safty, Mohamed Lotfy Mohamed, (2007): "Training needs of agricultural extension workers in the field of loading some vegetable crops on cotton crop in Gharbia and Beheira governorates", Journal of Agricultural Research, Kafr El-Sheikh University, Vol. 33, No. 1, March.

Ghaffar A, Taha AG (1975) Agricultural extension between philosophy and practice. New Press House, Alexandria

Hamdy YA (2006) "Organic agriculture in Egypt", 8th Conference of the Scientific Association of Agricultural Extension, "The role of agricultural extension in the development of Egyptian exports". Egyptian International Center for Agriculture, Cairo
Hassan, Mohamed Anwar Hussein (2000): "The role of agricultural extension in the dissemination and adoption of biocontrol practices among cotton farmers in Gharbia governorate", PhD Thesis, Faculty of Agriculture, Cairo University.

Kassem, Hazem (2003): "A safe agricultural ecological system to increase exports of horticultural crops", Agricultural Journal, No. 535, June, Ministry of Agriculture, Cairo.

Kelsey and Hearn (1963) Agricultural extension, Translated by Mohamed El Moallem. Egyptian Renaissance Library, Cairo

Kregice, R.V. and Morgan, D.W. "Educational and psychological measurement". College Station, Durham, North Carolina, U.S.A. (1970).

Sharaf JM (1990) An analytical study of the training needs of the use of agricultural pesticides among the extension agents in Mahmoudia Center. Master Thesis, Faculty of Agriculture, Alexandria University, Beheira Governorate

Specialized National Councils, Horizontal agricultural expansion, Technical Report No. 8, Cairo, 1990.

Tolba, Abdel-Rahman Farhat (2008): "Introducing organic agriculture and the laws regulating it", Specialized Training Course in Organic Agriculture, Central Laboratory for Organic Agriculture in association with CARE International Egypt.

\section{Publisher's Note}

Springer Nature remains neutral with regard to jurisdictional claims in published maps and institutional affiliations.

\section{Submit your manuscript to a SpringerOpen ${ }^{\circ}$ journal and benefit from:}

- Convenient online submission

- Rigorous peer review

- Open access: articles freely available online

High visibility within the field

- Retaining the copyright to your article

Submit your next manuscript at $\boldsymbol{\nabla}$ springeropen.com 